\title{
Evaluation of Electrolyzed Oxidizing Water for Management of Powdery Mildew on Gerbera Daisy
}

\author{
D. S. Mueller, Department of Plant Pathology, University of Georgia, Y.-C. Hung, Department of Food Science \\ and Technology, University of Georgia, and R. D. Oetting, Department of Entomology, University of Georgia, \\ Georgia Station, Griffin 30223; M. W. van Iersel, Department of Horticulture, University of Georgia, Athens \\ 30602; and J. W. Buck, Department of Plant Pathology, University of Georgia, Georgia Station, Griffin 30223
}

\begin{abstract}
Mueller, D. S., Hung, Y.-C., Oetting, R. D., van Iersel, M. W., and Buck, J. W. 2003. Evaluation of electrolyzed oxidizing water for management of powdery mildew on gerbera daisy. Plant Dis. 87:965-969.

Powdery mildew has been a major concern for greenhouse growers. Acidic electrolyzed oxidizing (EO) water was evaluated for the management of powdery mildew on gerbera daisy. EO water significantly reduced percent powdery mildew when sprayed twice a week and when sprayed every other week, alternating with fungicides. Studies were completed to determine if EO water could be used in an integrated management system. EO water was compatible with several fungicides and insecticides in an in vitro assay. However, EO water was not compatible with thiophanate methyl at the full rate and acephate at both the half and full rates. EO water is a viable option for controlling powdery mildew on gerbera daisies and provides growers an additional tool to reduce the use of traditional fungicides in greenhouses.
\end{abstract}

Gerbera (Gerbera jamesonii H. Bolus ex. Hook f.) or Transvaal daisy is a popular ornamental that is susceptible to powdery mildew. It is used as a cut flower and flowering pot plant as well as being widely used as a landscape bedding plant. Conditions conducive for powdery mildew development are cool night and warm day temperatures, closed plant canopy, high humidity, poor air circulation, and long periods of wet foliage (20). Powdery mildew can be easily identified by the whitish powder-like fungal growth on either leaf surface, and if left unchecked, on the stems and flowers.

An important tool for management of powdery mildew is the use of fungicides. Fungicides should be implemented on a need basis when environmental conditions are most conducive for powdery mildew development. Several products have been reported to provide adequate control of powdery mildews $(1,7,9,15-18)$. However, increasing concerns about the impact of pesticides on the environment, worker safety, and the appearance of fungicide resistance in target populations $(2,3,12$, $13,19)$ contribute to the need for alternative pest control measures. Cultural practices are used to prevent powdery mildew from becoming a problem, including adequately

Corresponding author: J. W. Buck

E-mail: jbuck@griffin.uga.edu

Accepted for publication 18 March 2003.

Publication no. D-2003-0519-04R

(C) 2003 The American Phytopathological Society spacing plants, removing leaves that overlap, reducing relative humidity, and providing adequate ventilation (20). These practices alone do not provide adequate control.

A potential alternative to traditional fungicides for control of powdery mildew is the use of acidic electrolyzed oxidizing (EO) water, which has gained attention from the food industry as a nonthermal method for sanitation (10). EO water has been demonstrated to sanitize food preparation surfaces and hospital equipment $(10,22,23)$. EO water is generated by electrolysis of a dilute salt solution in an electrolysis chamber where anode and cathode electrodes are separated by a nonselective membrane made from nonwoven polyester fabric (11). Water collected from the anode (EO water) has unique properties such as high oxidation-reduction potential (ORP), low $\mathrm{pH}$, and the presence of hypochlorous acid. These properties make EO water highly bactericidal $(4,10,22)$ and fungicidal (4). Little is known about the exact mechanism of EO water for microbial inactivation; although the high ORP has been proposed (11). In a study to determine potential phytotoxicity of EO water to bedding plants, application of the water three times per week caused minimal damage to the majority of species tested, and in general, EO water appears to be safe to use as a foliar spray (5).

The objectives of this study were: (i) to determine how effectively EO water will control powdery mildew development on gerbera daisy compared with a nontreated control and a fungicide treatment; (ii) to evaluate $\mathrm{EO}$ water in combination with fungicides in an integrated management system for control of powdery mildew on gerbera daisy; and (iii) to determine the compatibility of EO water with other pesticides, using Botrytis cinerea conidia as an in vitro model system.

\section{MATERIALS AND METHODS}

EO water. EO water was generated with a Hoshizaki ROX-20TA EO water generator (Hoshizaki Electric Co. Ltd., Toyoake, Aichi, Japan) at $14 \mathrm{~A}$ with a $2 \mathrm{M}$ stock solution of $\mathrm{NaCl}$ (certified A.C.S.; Fisher Scientific, Pittsburgh, PA). The $\mathrm{pH}$ and ORP of the EO water produced were measured with $\mathrm{pH}$ and ORP electrodes (model 50, ACCUMET meter; Denver Instrument Company, Denver, $\mathrm{CO}$ ) and ranged from $\mathrm{pH} 2.7$ to 2.8 and 1,050 to $1,053 \mathrm{mV}$, respectively. The free-chlorine concentration was determined by an iodometric method using a digital titrator (model 16900; Hach Company, Loveland, $\mathrm{CO}$ ) (22). Free-chlorine measurements were between 49 and $54 \mu \mathrm{g} \mathrm{ml}^{-1}$. EO water was generated and used within $1 \mathrm{~h}$ for each experiment.

Greenhouse experiments. Four-yearold gerbera plants were donated by a commercial grower, separated and repotted, and allowed to grow for 10 weeks. Plants were maintained in 2.5-liter pots containing Sunshine GBX potting mix (Sun Gro Horticulture Inc., Bellevue, WA). Gerberas were placed in a polyhouse with average night/day temperatures of 22 and $26^{\circ} \mathrm{C}$. Plants were irrigated through drip irrigation as needed and fertilized with Osmocote Plus 15-9-12 controlled release fertilizer (The Scotts Company, Marysville, $\mathrm{OH})$. Insect and arthropod pests were managed using standard practices.

Two separate experiments were conducted to evaluate EO water for controlling powdery mildew on gerberas. The goal of the first experiment was to evaluate EO water used as the only control measure. The treatments were (i) a nontreated check, (ii) EO water sprayed once a week, (iii) EO water sprayed twice a week, (iv) EO water diluted with distilled water (1:1) and sprayed once a week, (v) EO water diluted with distilled water (1:1) and sprayed twice a week, and (vi) triadimefon (0.6 $\mathrm{g} \mathrm{liter}^{-1}$; Strike, Bayer CropScience, Research Triangle Park, NC) sprayed once per week. The goal of the second experiment was to 
evaluate EO water used with fungicides in an integrated program. The treatments were (i) a nontreated check, (ii) EO water, (iii) triadimefon $\left(0.6 \mathrm{~g} \mathrm{liter}^{-1}\right)$ followed by one application of EO water, (iv) triadimefon $\left(0.6 \mathrm{~g} \mathrm{liter}^{-1}\right)$ followed by two applications of EO water, (v) piperalin $(0.60 \mathrm{ml}$ liter $^{-1}$; Pipron, SePRO Corporation, Carmel, IN) followed by one application of EO water, (vi) piperalin (0.60 ml liter $\left.{ }^{-1}\right)$ followed by two applications of EO water, and (vii) piperalin $\left(0.60 \mathrm{ml} \mathrm{liter}^{-1}\right)$. For this study, fungicides and/or EO water were only sprayed once a week. In both studies, all treatments were applied to leaf wetness using a hand sprayer for 7 weeks. In an effort to lower inoculum pressure, the nontreated check was changed to EO water sprayed twice a week after the fourth week in the first experiment. It was changed to EO water sprayed once a week after the second week in the second experiment.

Prior to the experiment, infected gerberas were dispersed evenly throughout the noninfected gerbera plants for 2 weeks and removed at the onset of the experiments. The severity of powdery mildew on each leaf of every plant was estimated weekly on the basis of percentage of leaf area exhibiting powdery mildew using the Horsfall-Barrett scale (8), and the ratings were converted to percent midpoint values (6). For week 0, a single mean value was generated for all treatments. Average severity values for each plant were calculated based on midpoint values. Also, area under dis- ease progress curve (AUDPC) values were calculated (21) based on the midpoints from week 0 through week 7 . Early in the first experiment, plants had an average of 10 leaves, and at the end of the study they had an average of 25 leaves. At the end of each week, flowers were removed and totaled throughout the experiment. Early in the second experiment, plants had an average of 15 leaves, and at the end of the study they had an average of 30 leaves. There were two plants per replication and four replications. Plants were arranged in a randomized complete block design, and the experiment was repeated.

Compatibility with pesticides. Conidia of $B$. cinerea were stored in $15 \%$ glycerol at $-70^{\circ} \mathrm{C}$. Cultures were started on potato dextrose agar (PDA; Difco Laboratories, Detroit, MI), and conidia were harvested after 2 weeks. The culture was flooded with $10 \mathrm{ml}$ of $0.05 \%$ Tween 20 (J. T. Baker, Phillipsburg, NJ), conidia were dislodged with a glass rod, and the resulting suspension was filtered through five layers of sterile cheesecloth. The conidia were pelleted, resuspended in sterile distilled water, and adjusted to $1 \times 10^{5}$ conidia per ml. A $100-\mu l$ volume of the conidial suspension was combined with $10 \mathrm{ml}$ of different pesticide solutions in distilled water or EO water at half and full recommended rates (Table 1). Fungicides tested were azoxystrobin (Heritage; Syngenta Professional Products, Greensboro, NC), fenhexamid (Decree; SePRO Corporation),

Table 1. Percent germination of Botrytis cinerea conidia treated with pesticides mixed with distilled water $\left(\mathrm{dH}_{2} \mathrm{O}\right)$ or electrolyzed oxidizing $(\mathrm{EO})$ water

\begin{tabular}{|c|c|c|c|c|c|}
\hline \multirow[b]{3}{*}{ Pesticide treatment } & \multirow{3}{*}{$\begin{array}{l}\text { Rate (a.i./liter } \\
\text { water) }\end{array}$} & \multicolumn{4}{|c|}{ Germination $(\%)^{a}$} \\
\hline & & \multicolumn{2}{|c|}{ Trial 1} & \multicolumn{2}{|c|}{ Trial 2} \\
\hline & & $\mathrm{dH}_{2} \mathrm{O}$ & EO water & $\mathbf{d H}_{2} \mathrm{O}$ & EO water \\
\hline \multicolumn{6}{|l|}{ Checks } \\
\hline No treatment & $\ldots$ & $97 \pm 1.0^{\mathrm{b}}$ & $0 \pm 0.0$ & $99 \pm 0.6$ & $0 \pm 0.0$ \\
\hline Triton X-100 & $\ldots$ & $98 \pm 0.1$ & $0 \pm 0.0$ & $98 \pm 0.7$ & $0 \pm 0.0$ \\
\hline \multicolumn{6}{|l|}{ Fungicides } \\
\hline \multirow[t]{2}{*}{ Azoxystrobin } & $0.15 \mathrm{~g}$ & $98 \pm 1.1$ & $0 \pm 0.0$ & $98 \pm 0.8$ & $0 \pm 0.0$ \\
\hline & $0.30 \mathrm{~g}$ & $99 \pm 1.1$ & $0 \pm 0.0$ & $98 \pm 0.5$ & $0 \pm 0.0$ \\
\hline \multirow[t]{2}{*}{ Fenhexamid } & $0.90 \mathrm{~g}$ & $7 \pm 3.3$ & $4 \pm 2.0$ & $4 \pm 1.7$ & $4 \pm 1.4$ \\
\hline & $1.80 \mathrm{~g}$ & $0 \pm 0.0$ & $0 \pm 0.0$ & $0 \pm 0.0$ & $0 \pm 0.0$ \\
\hline \multirow{2}{*}{ Myclobutanil } & $0.30 \mathrm{~g}$ & $98 \pm 1.7$ & $0 \pm 0.0$ & $98 \pm 1.1$ & $0 \pm 0.0$ \\
\hline & $0.60 \mathrm{~g}$ & $98 \pm 0.9$ & $0 \pm 0.0$ & $99 \pm 0.4$ & $0 \pm 0.0$ \\
\hline \multirow[t]{2}{*}{ Piperalin } & $0.30 \mathrm{ml}$ & $22 \pm 2.5$ & $0 \pm 0.0$ & $97 \pm 1.9$ & $0 \pm 0.0$ \\
\hline & $0.60 \mathrm{ml}$ & $2 \pm 1.6$ & $0 \pm 0.0$ & $29 \pm 3.5$ & $0 \pm 0.0$ \\
\hline \multirow[t]{2}{*}{ Thiophanate methyl } & $0.90 \mathrm{~g}$ & $97 \pm 1.0$ & $0 \pm 0.0$ & $98 \pm 0.4$ & $0 \pm 0.0$ \\
\hline & $1.80 \mathrm{~g}$ & $97 \pm 0.3$ & $97 \pm 1.2$ & $98 \pm 0.4$ & $98 \pm 0.9$ \\
\hline \multirow[t]{2}{*}{ Triadimefon } & $0.30 \mathrm{~g}$ & $98 \pm 0.8$ & $0 \pm 0.0$ & $98 \pm 0.4$ & $0 \pm 0.0$ \\
\hline & $0.60 \mathrm{~g}$ & $98 \pm 1.3$ & $0 \pm 0.0$ & $98 \pm 0.8$ & $0 \pm 0.0$ \\
\hline \multicolumn{6}{|l|}{ Insecticides } \\
\hline \multirow{2}{*}{ Abamectin } & $0.30 \mathrm{ml}$ & $98 \pm 0.8$ & $0 \pm 0.0$ & $97 \pm 0.4$ & $0 \pm 0.0$ \\
\hline & $0.60 \mathrm{ml}$ & $97 \pm 0.9$ & $0 \pm 0.0$ & $99 \pm 0.3$ & $0 \pm 0.0$ \\
\hline \multirow[t]{2}{*}{ Acephate } & $0.40 \mathrm{~g}$ & $98 \pm 1.2$ & $97 \pm 0.6$ & $98 \pm 0.2$ & $98 \pm 0.3$ \\
\hline & $0.80 \mathrm{~g}$ & $97 \pm 2.3$ & $97 \pm 0.9$ & $98 \pm 0.6$ & $98 \pm 0.6$ \\
\hline \multirow[t]{2}{*}{ Imidacloprid } & $0.15 \mathrm{ml}$ & $98 \pm 0.5$ & $0 \pm 0.0$ & $99 \pm 0.8$ & $0 \pm 0.0$ \\
\hline & $0.30 \mathrm{ml}$ & $98 \pm 1.1$ & $0 \pm 0.0$ & $98 \pm 0.7$ & $0 \pm 0.0$ \\
\hline \multirow[t]{2}{*}{ Spinosad } & $0.50 \mathrm{ml}$ & $99 \pm 0.8$ & $0 \pm 0.0$ & $97 \pm 0.7$ & $0 \pm 0.0$ \\
\hline & $1.00 \mathrm{ml}$ & $97 \pm 0.9$ & $0 \pm 0.0$ & $98 \pm 0.2$ & $0 \pm 0.0$ \\
\hline
\end{tabular}

a Percent germination was calculated from the mean of four replications after $18 \mathrm{~h}$ of incubation on potato dextrose agar at $25^{\circ} \mathrm{C}$. Germination was assessed microscopically for a minimum of 200 conidia per replication.

${ }^{\mathrm{b}}$ Data presented as means \pm standard error. myclobutanil (Systhane; Dow AgroSciences, Indianapolis, IN), piperalin, thiophanate methyl (Cleary 3336; Cleary Chemical Corporation, Dayton, NJ), and triadimefon. Insecticides tested were abamectin (Avid; Syngenta Professional Products), acephate (Orthene; Arvesta Corporation, San Francisco, CA), imidacloprid (Marathon II; Olympic Horticultural Products, Mainland, PA), and spinosad (Conserve; Dow AgroSciences). Also, the surfactant Triton X-100 (Fisher Scientific) was tested at a rate of $0.06 \%$. Two $50-\mu l$ drops of each treatment were placed on four separate PDA plates (one plate equals a replication) and incubated at $25^{\circ} \mathrm{C}$ for $18 \mathrm{~h}$. Germination was assessed microscopically for a minimum of 200 conidia per replication.

Data analysis. Experiments in the greenhouse were arranged in randomized complete block designs with four replications. Data for the two plants within each replication were averaged prior to analysis. Each experiment was completed twice. The number of flowers, percent powdery mildew severity for weeks 2 through 7 , and AUDPC values were subjected to analysis of variance using general linear models procedure (PROC GLM) of SAS (SAS Institute Inc., Cary, NC). For each of these experiments, repetitions and replications were considered random variables, while treatments were considered fixed variables. Means were separated by Fisher's protected least significant difference (LSD) at $P=0.05$. Data from the pesticide compatibility experiment are reported as the mean \pm standard error because they could not be analyzed with ANOVA due to the quantity of zeros and treatment effects are obvious.

\section{RESULTS}

Greenhouse experiments. In the first greenhouse experiment, the repetitions were combined because there was no significant trial by treatment interaction $(P=$ 0.10 ). Powdery mildew was estimated at $33 \%$ at the onset of the experiments (Fig. 1). The nontreated check plants had over $80 \%$ powdery mildew 3 and 4 weeks after the experiment was started. Consequently, the nontreated check plants were sprayed twice a week with EO water, and the powdery mildew subsequently dropped to $32 \%$ by week 7 . This treatment was removed from the final analysis for weeks 5 through 7, and the AUDPC value was not calculated through this time period. For the triadimefon treatment, the AUDPC value (106) and powdery mildew severity at week $7(6 \%)$ were lower $(P<0.05)$ than for all EO water treatments (Fig. 1). EO water sprayed twice a week had a significantly lower $(P<0.05)$ AUDPC value (172) and powdery mildew severity at week $7(12 \%)$ than the other EO water sprayed once a week and diluted EO water spray once or twice a week (Fig. 1). EO water did not affect the number of flowers 
produced compared with both the fungicide and nontreated check. However, the plants that we sprayed twice per week with EO water showed some phytotoxicity, which included some wrinkling and brittle leaves.

In the second greenhouse experiment where EO water and fungicides were sprayed in different sequences, data from the two trials were combined because there was no significant trial by treatment interaction $(P=0.60)$. Powdery mildew levels were estimated at $48 \%$ at the beginning of the experiment. The nontreated check plants had over $68 \%$ powdery mildew severity 2 weeks after the experiment was started, and in an effort to lower inoculum pressure, the nontreated check plants were sprayed with EO water. After 5 weeks of EO water, the powdery mildew severity was lowered to $44 \%$. This treatment was removed from the final analysis for weeks 4 through 7 and the AUDPC value. AUDPC values and powdery mildew levels at week 7 in treatments with EO water alternating weekly with piperalin or triadimefon were significantly lower than in treatments with EO water only or EO water applied for 2 weeks between fungicide sprays (Fig. 2). EO water alternated with either fungicide did not affect the number of flowers produced compared with the fungicide and nontreated checks. There were more flowers produced in the piperalin treatment (2.9 flowers per pot) than in the treatment with EO water sprayed once per week (1.3 flowers per pot) and the nontreated check (1.8 flowers per pot).

Although the nontreated checks were amended during each of these studies, the original sources of inoculum that were removed at the onset of each study remained nontreated. These plants were maintained in another area of the greenhouse under the same conditions, and all of the plants had average powdery mildew severity exceeding $80 \%$ by the end of both experiments (personal observation).

Compatibility with pesticides. There was a significant trial by treatment interaction $(P<0.01)$, so data from both trials are presented. Ninety-seven to $99 \%$ of the $B$. cinerea conidia germinated with $\mathrm{dH}_{2} \mathrm{O}$ treatments, and none of the conidia germinated in EO water (Table 1). The isolate of $B$. cinerea was sensitive to fenhexamid and piperalin; all other pesticides did not affect germination when mixed with $\mathrm{dH}_{2} \mathrm{O}$. Fenhexamid at both rates, thiophanate methyl at the full rate, and acephate at both rates were the only pesticides in which conidia germinated when mixed with EO water (Table 1).

\section{DISCUSSION}

Powdery mildew is a widely distributed and destructive disease of greenhousegrown ornamental plants. Fungicideresistant strains of the pathogens and worker safety are two major concerns for greenhouse growers and justify the need for alternative methods for disease control. Our evaluation of EO water as a potential alternative to fungicides clearly demonstrated that EO water could control powdery mildew on gerberas.

Although proper management may delay or lower powdery mildew outbreaks, control is often achieved primarily by the use of fungicides. Development of fungicideresistant strains of powdery mildew pathogens has been reported on several crops $(2,3,12,13,19)$. Inorganic salts such as sodium bicarbonate and phosphate and potassium salts have been used successfully in controlling powdery mildew on cucumber and rose $(9,15,17,18)$. EO water significantly reduced lesion formation by $B$. cinerea on geranium leaf disks (4). However, prior to our study, no full-scale greenhouse trials of EO water for powdery mildew control had been conducted. In a previous report, EO water quickly killed a wide variety of fungal spores and hyphae in addition to several bacteria (4). This quick activity facilitates the use of EO water as a contact fungicide on aerial plant surfaces.

Commercial greenhouse growers commonly apply pesticides once a week. Both a fungicide and an insecticide may be needed some weeks. EO water can be neutralized by nonselective reducing agents (14) and high concentrations of surfactant (4). Our study looked at several different pesticides as well as the recommended rate

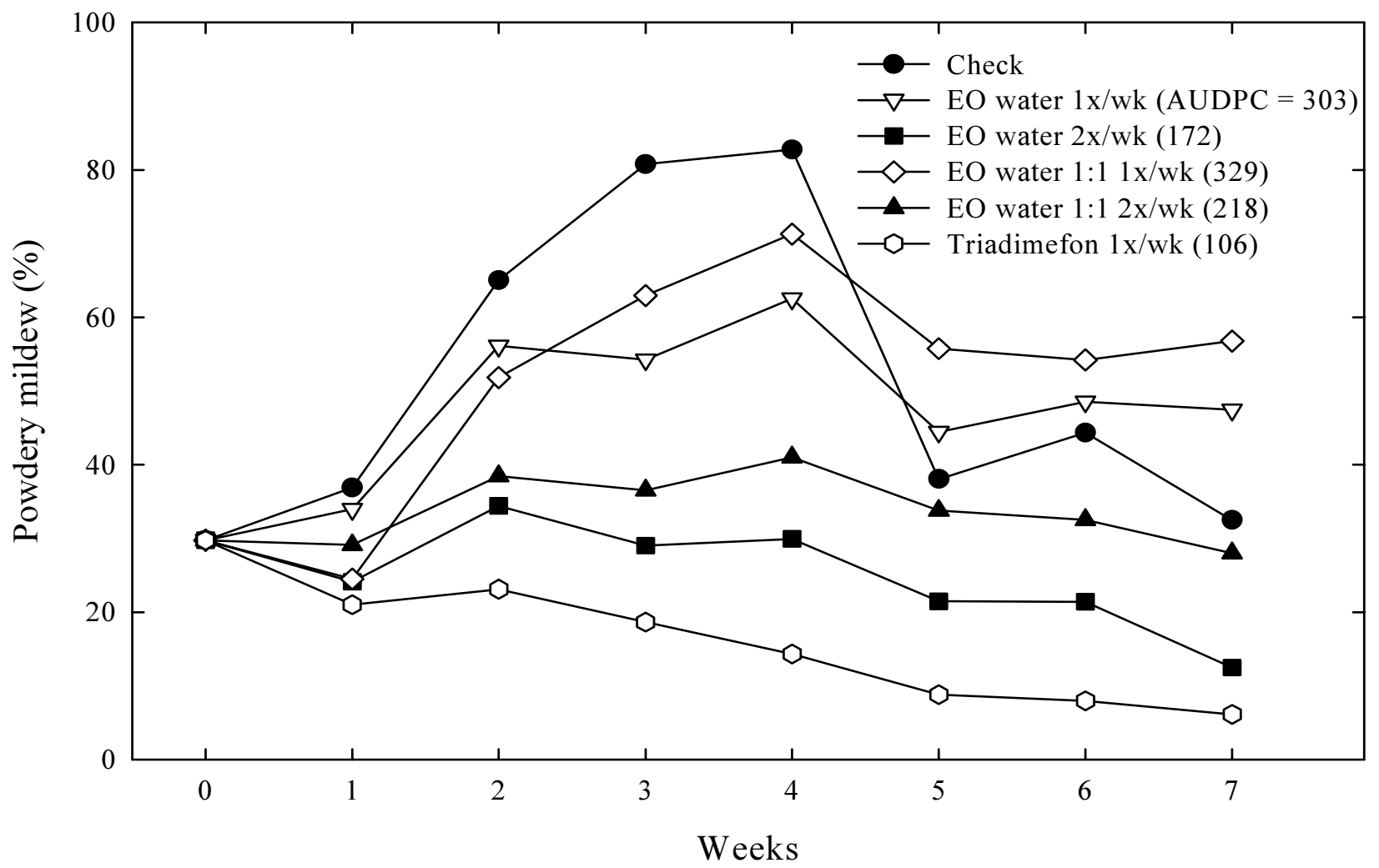

Fig. 1. Powdery mildew severity on greenhouse-grown gerberas treated with different dilutions and amounts of electrolyzed oxidizing water (EO water) and triadimefon for 7 weeks. Data points represent the mean values of two plants from four replications over two experiments. The LSD values $(0.05)$ for percent powdery mildew severity for weeks 2 through 7 and the AUDPC value (numbers in parentheses in the legend) were 9.8, 8.2, 8.1, 6.1, 5.9, 5.5, and 31 , respectively. After week 4, the nontreated check was changed to EO water sprayed twice per week. 


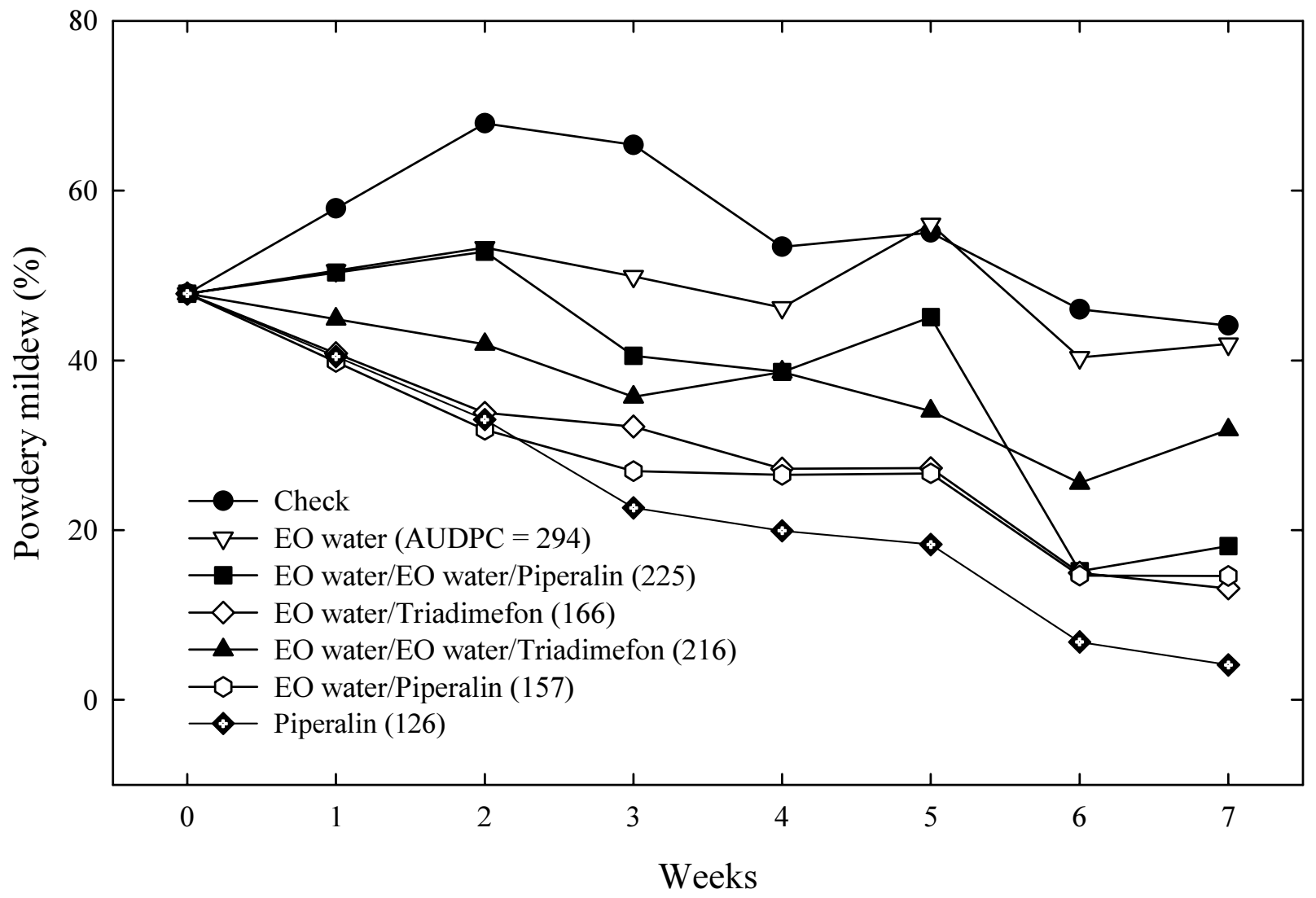

Fig. 2. Percent powdery mildew of gerberas in the greenhouse with different combinations of fungicides and electrolyzed oxidizing water (EO water). Data points represent mean values of two plants from four replications over two experiments. The LSD values $(0.05)$ for percent powdery mildew for weeks 2 through 7 and the AUDPC value (numbers in parentheses in the legend) were 9.1, 10.1, 7.7, 7.2, 7.3, 4.4, and 30, respectively. After week 3, the nontreated check was changed to EO water sprayed once per week.

of the surfactant Triton X-100. The isolate of $B$. cinerea used was sensitive to fenhexamid but not sensitive to thiophanate methyl (unpublished data). At the full rate of fenhexamid, no conidia germinated; however, at the half rate, an average of 5.5 and $4 \%$ of the conidia germinated in distilled and EO water, respectively. In the thiophanate methyl treatment, over $97 \%$ of the conidia germinated at the full rate with EO water; however, when using the half rate with EO water, none of the conidia germinated. One insecticide, acephate, neutralized EO water at both rates. From these data, it appears that both the amount of product as well as the chemistry of the product will determine if a particular pesticide will be compatible with EO water. Fortunately, none of the other pesticides tested negatively affected the efficacy of EO water against $B$. cinerea conidia. This could allow growers to use EO water in an integrated system, complementing certain fungicides or insecticides currently used.

EO water and other disinfectants have no systemic activity and ideally should be used as a preventative treatment. This is a problem if trying to effectively control powdery mildew. In both of our greenhouse studies, powdery mildew initially was estimated at over $30 \%$. The EO water treatment reduced powdery mildew, but on plants that received no systemic fungi- cides, powdery mildew quickly reappeared (personal observation). To effectively control powdery mildew in the greenhouse, EO water may need to be applied prior to or shortly after the onset of the disease. Another option would be to spray multiple applications per week. However, the plants that we sprayed twice per week with EO water showed some phytotoxicity, which included some wrinkling and brittle leaves. We saw very little, if any, phytotoxicity on the plants sprayed once per week, especially when used in combination with fungicides.

When used in an integrated system, EO water was successful in reducing powdery mildew. EO water was also effective when combined with most pesticides. These studies have demonstrated that EO water, when used in an integrated management system, may be used in the greenhouse to reduce fungicide use for control of powdery mildew on gerbera daisy.

\section{ACKNOWLEDGMENTS}

We acknowledge the technical assistance of R. Estes, M. Jarrett, and R. Stinchcomb. We also thank Dave Vickery's greenhouse (Thomaston, GA) for their generous donation of plant and planting material. This research was supported by a grant from the USDA Pest Management Alternatives Program (Award \# 2001-34381-11180).

\section{LITERATURE CITED}

1. Bettiol, W. 1999. Effectiveness of cow's milk against zucchini squash powdery mildew
(Sphaerotheca fuliginea) in greenhouse conditions. Crop Prot. 18:489-492.

2. Blatter, R. H. E., Brown, J. K. M., and Wolfe, M. S. 1998. Genetic control of the resistance of Erysiphe graminis f. sp. hordei to five triazole fungicides. Plant Pathol. 47:570-579.

3. Brown, J. K. M. 2002. Comparative genetics of avirulence and fungicide resistance in the powdery mildew fungi. Pages 56-65 in: The Powdery Mildews: A Comprehensive Treatise. R. R. Belanger, W. R. Bushnell, A. J. Dik, and T. L. W. Carver, eds. American Phytopathological Society, St. Paul, MN.

4. Buck, J. W., van Iersel, M. W., Oetting, R. D., and Hung, Y.-C. 2002. In vitro fungicidal activity of acidic electrolyzed oxidizing water. Plant Dis. 86:278-281.

5. Buck, J. W., van Iersel, M. W., Oetting, R. D., and Hung, Y.-C. 2003. Evaluation of acidic electrolyzed water for phytotoxic symptoms on foliage and flowers of bedding plants. Crop Prot. 22:73-77.

6. Campbell, C. L., and Madden, L. V. 1990. Introduction to Plant Epidemiology. John Wiley \& Sons, New York.

7. Cruger, G. 1985. Different ways of powdery mildew control. Acta Hortic. 156:221-227.

8. Horsfall, J. G., and Barrett, R. W. 1945. An improved grading system for measuring plant disease. Phytopathology 35:655.

9. Horst, R. K., Kawamoto, S. O., and Porter, L. L. 1992. Effect of sodium bicarbonate and oils on the control of powdery mildew and black spot of roses. Plant Dis. 76:247-251.

10. Kim, C., Hung, Y.-C., and Brackett, R. E. 2000. Efficacy of electrolyzed oxidizing (EO) and chemically modified water on different types of foodborne pathogens. Int. J. Food Microbiol. 61:199-207. 
11. Kim, C., Hung, Y.-C., and Brackett, R. E. 2000. Rules of oxidation-reduction potential in electrolyzed oxidizing and chemically modified water for the inactivation of foodrelated pathogens. J. Food Prot. 63:19-24.

12. McGrath, M. T. 1996. Increased resistance to triadimefon and to benomyl in Sphaerotheca fuliginea populations following fungicide usage over one season. Plant Dis. 80:633-639.

13. McGrath, M. T., Staniszewska, H., Shishkoff, N., and Casella, G. 1996. Fungicide sensitivity of Sphaerotheca fuliginea populations in the United States. Plant Dis. 80:697-703.

14. Oomori, T., Oka, T., Inuta, T., and Arata, Y. 2000. The efficiency of dininfection of acidic electrolyzed water in the presence of organic materials. Anal. Sci. 16:365-369.

15. Pasini, C., D'Aquila, F., Curir, P., and Gullino, M. L. 1997. Effectiveness of anti- fungal compounds against rose powdery mildew (Sphaerotheca pannosa var. rosae) in glasshouses. Crop Prot. 16:251-256.

16. Rasche, E. 1985. Control of powdery mildew on greenhouse cucumber with pyrazophos. Acta Hortic. 156:237-243.

17. Reuveni, M., Agapov, V., and Reuveni, R. 1996. Controlling powdery mildew caused by Sphaerotheca fuliginea in cucumber by foliar sprays of phosphate and potassium salts. Crop Prot. 15:49-53.

18. Reuveni, R., Agapov, V., Reuveni, M., and Raviv, M. 1994. Effects of foliar sprays of phosphates on powdery mildew (Sphaerotheca pannosa) of roses. J. Phytopathol. 142:331-337.

19. Schroeder, W. T., and Provvidenti, R. 1969. Resistance to benomyl in powdery mildew of cucurbits. Plant Dis. Rep. 53:271-275.
20. Tija, B. 1984. Gerbera production and its problems. Proc. Int. Plant Propagators' Soc. 365-375.

21. Tooley, P. W., and Grau, C. R. 1984. Field characterization of rate-reducing resistance to Phytophthora megasperma f. sp. glycinea in soybean. Phytopathology 74:1201-1208.

22. Venkitanarayanan, K. S., Ezeike, G. O., Hung, Y.-C., and Doyle, M. P. 1999. Efficacy of electrolyzed oxidizing water for inactivating Escherichia coli 0157:H7, Salmonella enteritidis, and Listeria monocytogenes. Appl. Environ. Microbiol. 65:4276-4279.

23. Venkitanarayanan, K. S., Ezeike, G. O., Hung, Y.-C., and Doyle, M. P. 1999. Inactivation of E. coli $\mathrm{O} 157: \mathrm{H} 7$ and Listeria monocytogenes on plastic kitchen cutting boards by electrolyzed oxidizing water. J. Food Prot. 62:857860 . 